UDC 061.2(008+796)(1-22)

DOI: https://doi.org/10.30839/2072-7941.2019.177740

\title{
DEVELOPMENT OF CULTURAL AND SPORTING ACTIVITIES IN VILLAGES
}

\author{
CJARUŠEVIČIENE, LINA \\ Marijampole college (Marijampole, Lithuania) \\ E-mail: lin.jaru@mkolegija.lt, ORCID iD : 0000-0002-1058-4877
}

\begin{abstract}
In large and small villages, regardless of tourist attraction, cultural life is faded; people's initiative is low as urban migration is extremely high. Many ethnographic villagers do not realize that they live in a significant for the state areas. The younger generation is embarrassed by local traditions, folklore. The low level of aesthetic education (music, art, design, architecture), and the poor possibilities of organizing artistic celebrations for the younger generation make them the users of the lowest level of urban culture. The relevance of the research: employees of Lithuanian rural culture centers - a group uniting almost three thousand people, invited to make sense of rural people's leisure time, to create conditions for the development of amateurism in small villages. 882 country cultural centers in villages, towns and cities are institutions of universal use or specific activities. Their work varies, depending on what traditions have formed, the ambitions of the district or eldership that local cultural and sports departments seek. You will not find a cultural center where they would not sing, dance, play, perform, or celebrate. Also, exhibitions are regularly opened. Obviously, more intensive activity takes place in metropolitan areas, district centers, and in resorts during the summer. As here there is more space, more culture and more communities. Village and town culture institutions that are constantly communicating with schools, libraries, religious communities, neighborhoods, and sports clubs are also gaining significant results. However, it is appropriate to move to specific data from the theoretical point of view. Those members of rural communities who go in for sport individually face health supervision problems. Inadequate attention is paid to the development of personal responsibility for one's health and the promotion of a healthy life: proper nutrition, active rest, less health-hazardous environment, abandoning harmful habits and etc. in an environment contrary to life in the countryside. It is important to develop a physically active and healthy society, consciously aware of the importance of a healthy lifestyle, to create a favorable environment for leisure time and sport and for the improvement of health of rural population, moreover, to increase the development of physical education and sports services in rural districts of Lithuania, to increase the quality of sports services, giving rural residents wider opportunities to meet their needs. The problem of the research: the lack of cultural and sporting services in rural communities. The analysis of the problem is based on scientific data of Aleksandravičius and Žukovskis (2011), Baršauskienė, Leliūgienė (2014), Kroeber A., Kluckhohn (1952), Nefas (2007, 2008), Paulikas, Adomonis (2003), Putnam (2001), Biologur (2013,2018), documents regulating the activities of rural communities. Methodology of the research: In order to achieve the goal, the analysis and synthesis of scientific literature, legal documents and other information sources and statistical data are used. The aim of the research: to reveal the factors of cultural and sports development in rural communities. Research objectives: to describe the development of cultural and sports services in the context of rural communities' activities; to identify the most significant factors in the development of cultural and sporting services in rural communities. Conclusion. Activities carried out by organizations of rural communities include a wide range of community needs, including the organization of cultural and sporting events, improvement of environmental management assistance, and others. As the main problems of rural community activities, the poor condition of rural social
\end{abstract}


infrastructure objects are mentioned, therefore the process of establishment of community centers for the establishment of universal multifunctional centers is one of the significant tools for the development of rural communities and thus the development of cultural and sports activities.

Keywords: Communities, rural communities, development, cultural services, sports services.

\section{Cultural and sporting services in} the context of community development.

Defining culture precisely and unambiguously is extremely difficult. It is said that about 150 definitions of cultural concept have been created. The idea of culture, like all important ideas, was a work of many great minds and it was gradually developed. There are still large civilized nations that, according to Kroeber, a prominent American anthropologist, refuse to include the word 'culture' in their intellectual vocabulary. On the other hand, both the ancient people and the inhabitants of the poorly civilized countries know some cultural phenomena, such as specific customs. "We are not doing that, we do this" - such an affirmation is the recognition of a cultural phenomenon. In certain situations and contexts, the concept of culture is inherent in the concept of society. Culture can only exist if there is a society, and on the contrary, every society has a particular culture. It should be emphasized that culture can only be created and functioned in the human community. Culture encompasses all aspects of group activity - thinking, belief, cognition, and feelings that have accumulated through the long ages of social group existence and have been passed down from generation to generation [6]. Social groups mean different attitudes, beliefs and feelings. It is embedded in different cultural ideals, superstitions, logic, stereotypes, word, music, visual arts, and technical creation, ranging from a simple arrow to an airplane. Culture consists of well-established patterns of thinking, sensation and reaction, with the help of symbols acquired and transmitted. Culture is based on traditional, historically tested ideas and values. Culture has not only content but also structure. Culture is like a "plan of life" that has settled in the course of history. Both parts of the culture must be taken into account when studying culture: visible and understandable, and hidden, symbolic side of culture [6]. Culture is a system of meanings that members of that culture give to individuals and the environment that make up that culture. Culture encompasses the whole body of ideas and material things created by human society and adapted to life. Culture is a product of human activity, but at birth a person already enters the appropriate culture that has been created before. Currently the main goal of municipal culture workers is to preserve and foster ethnic culture and local traditions, to develop and improve educational activities of cultural institutions, to form and develop cultural communities of municipal elderships and villages, to create conditions for purposeful, coordinated and integrated implementation of municipal education, cultural institutions, non-governmental 
organizations. The practice of the last two decades shows that the preservation and nurturing of ethnographic and ethical (moral) heritage can effectively serve the development of civil society, shaping the value orientation. This feature is implemented by:

1. Collection of narrative folklore, folk songs, scenic expressions and other verbal creations;

2. The development of regional research, the use of neighborhood history in both formal and non-formal education;

3. Restoration of ethnographic crafts and traditional rural businesses, analysis of elements of ethnographic creation in extracurricular activities of young learners, as well as organizing specialized seminars, creative camps, exhibitions, competitions, activities in craft centers, etc .;

4. Development of new tourist routes for the study of ethnographic, historical and literary heritage;

5.The study of moral heritage (communication style, lifestyle, customs, traditions, etc.) through educational and cultural institutions, religious organizations and local communities [5].

In the scientific literature, the concept of community is usually analyzed as a description of certain qualities and relationships. Communion in a group of people manifests itself as a certain unification of joint efforts and resources. Nefas (2007, 2008), describing the functionality of a local community, states that the functionality of local communities in modern Lithuanian villages and towns has lost its two aspects: one provides an important institutional foundation that enables community initiatives to be implemented, and other public administration to learn; the other is that in many places in Lithuania artificial communities have emerged, the only purpose of which is to get EU support. Sometimes these unnaturally formed communities are created as an alternative to the remains of natural communities (such as parishes). In Lithuania, this problem was first raised by Paulikas and Adomonis [10] who mentioned the restoration of functionality as one of the criteria for the functioning of public institutions, as well as the expression of the dimension of democratic governance (real self-government). Meanwhile, it is noticeable that in Western countries social capital is constantly recovering by strengthening local government (municipality, elderships) and local institutions (churches, schools, cultural institutions, etc.) and civic initiatives. Defining the concept of a functional local community, the definition of D. Corten Organization (NGO) should be used, according to which NGOs are characterized by volunteering, citizenship and participation in the provision of public services and public policy [8,9]. Local communities are most different from NGOs because they do not formalize their activities. It is therefore suggested to define a functional local community as follows: a functional local community is a group of people living in a defined area and performing certain activities for the benefit of that place, which creates a common interest and an inner feeling that they belong to the same group of people. A functional local community 
can be defined by the following key criteria:

- Communication system is in operation;

- explores spiritual values, ethnoculture, and therefore creates a favorable environment for the community's individual to grow and develop;

- interaction between individuals, neighbors, groups, organizations takes place;

- Social order development;

- Individuals trust themselves and their neighbors;

- Democratic principles are implemented.

What is called here a functional local community in the Western countries is called a civil society, and it is defined as being characterized by citizen participation in public affairs, and their interrelationship is based on horizontal mutual and interpersonal relationships, based on mutual respect and trust, even when attitudes towards the essentials are different [10], or neighborhood, which is an area where the population occupies certain spaces of life; use the same services and shared facilities, participate in the same activity: take care, strive to maintain and improve material things, spiritualize community life, enrich the environment, which also requires commitment. Both local communities and civil society or neighborhood cannot be confused with longstanding institutions in the western countries, though, in Lithuania rapidly developing only in recent years, as it has been mentioned earlier. The place where different ages, different levels of education, diverse societies meet, people who come here to unite their knowledge, combine their experience and desire to learn, study common problems, work for the same purpose [2]. This is nothing more than one or more community organizations in the local community that are formal.

At present, the formation of rural communities has been influenced by movements of ethnic minorities by ethnographic regions and associations of rural women farmers. The main goal of rural communities in Lithuania is to encourage the population to try to improve their living conditions, motivate them for self-help and cultural self-expression, to strengthen the expressions of solidarity and community, and to prevent the spread of social exclusion. It is precisely from the social development of the communities that the economic growth of the population may begin, which is crucial for creating the right conditions for sustainable rural development [1]. To sum up, the concept of "community" also includes other concepts, the formation of which was influenced by the conditions and factors of different periods, although the main unifying relationship - "common", "community" - remains at all times. From the point of view of public law, the rural community is a municipal unit for local affairs. The local community is the population of the municipality's residential area (part of it or several residential areas), linked to the common needs and interests of the neighborhood and meeting these needs and interests through various forms of direct participation (meeting, public hearing, survey, activity through their representatives, community organizations and etc. [10] 
In the application of these definitions, the community can form a compact group of people living in the territory of a local municipality, which may be a municipality or an eldership, but there may be several independent communities within the territory of one local self-government. The laws of Lithuania do not preclude the villages from having their own community. The same situation should be in towns where there may be several communities with different local names in the territory of an eldership. It would be appropriate to describe the community as a group of people sharing the same space, similar experiences and / or similar interests, pursuing commonly formulated goals. The rapid growth of the number of organizations in rural communities is determined by various objectives and expectations of material and ideological nature. However, the objectives formulated by the organizations themselves are not so much the desire to create something new, but to correct the current situation. The main goal of rural communities in Lithuania is to encourage people to try to improve their own living conditions, increase reliance on self-help and motivate cultural self-expression, to reinforce the manifestations of solidarity, to prevent the spread of social exclusion trends. Activities carried out by rural community organizations cover a wide range of community needs. They are involved in the organization of cultural and sporting events, preparation of environmental management tasks, take care of leisure activities of children and youth, improvement of rural infrastructure, education of inhabitants, solving of rural social problems, representation of inhabitants in governmental institutions, etc. The following main problems of rural communities can be distinguished: lack of information and some services in rural areas, poor condition of rural social infrastructure objects, limited economic development opportunities and dependence of rural population on social support system; low community interest in solving their own problems. One of the possible obstacles to the development of new activities is the lack of competence and skills of community leaders.

There is no lack of young people in rural areas, more and more young people studying in metropolitan areas are eager to visit parents and grandparents in homesteads, actively participate in community life, offer new ideas and try to implement them. New technologies transform the approach to life in the area - access to information services is unlimited, but a person who lives in a clean environment, has more space and freedom. Indeed, the approach to the village is increasingly changing - rural areas are improving and getting better every year, and projects funded by the European Union are attracting more and more young entrepreneurs. According to Jasaitis (2014), studies show that the rural population of the new categories appreciates the relaxation and rehabilitation effects of the countryside. This feature is implemented in several directions:

1. Creating new wellness and sports areas tailored to the needs of both mass and small groups, families and individuals; 
2. New types of nature entertainment are being developed, as well as infrastructure for them;

3. Organizations', collectives' and personal celebrations are organized in the countryside. New objects are being built for these needs, reconstructed manor complexes are being adapted, etc

4. The role of the institute of religion in rehabilitation and resocialization processes is restored. Pilgrimage tourism, youth camps, churches and monasteries and their environmental management talks are becoming more popular.

The main goals of sport as leisure and recreational activities are to create conditions for municipal residents to systematically engage in physical education and sports, to develop mass sports, to guarantee access to sport for everyone, to provide access to school sports bases and inventory for municipal residents, to achieve the introduction of the third physical education lesson at schools, to provide the right conditions for cultivating sport and physical education. The value benchmarks of the concept of sport as a social system, a social institution and a social movement expressing its cultural core are revealed; it is proved that modern sport as a social system, social institute and social movement is an effective means to overcome the crisis phenomena of modern civilization $[3,4]$.

Studies have shown that rural areas have not yet developed a relaxation and rehabilitation function. Although the demand for this type of service is constantly increasing, a very small proportion of the available recreational resources have been used up to the recent time. Unlike residents of many Western countries, Lithuanian society is not yet able to get rid of the health-obsessive routine. There is a lack of appropriately equipped places suitable for rehabilitation, during post-operative and post-traumatic periods. And the persistent tensions in workplaces and in the public environment, new qualification requirements for professionals, the challenges of globalization, even the problems of personal life, are leading to a rapid increase in the value of the so-called recreational industry. According to Jasaitis (2014), restoring the economic and cultural vitality of these areas, which has recently dwindled drastically, can be achieved through the development of alternatives to agriculture, which means nonagricultural businesses. The need for more efficient use of local resources and renewable energy sources also creates a favorable environment for economic activity. Such diversification, based on the creation of new jobs for educated people, increases the attractiveness of economic and socio-cultural potential of these areas.

It is planned that in rural areas where no more than 1000 inhabitants live, new types of services for the population - multifunctional centers should emerge. 60 percent of multifunctional center activities should be devoted to education: preschool, pre-school children can be trained here, mother-child groups are created for young children, where parents together with their children improve their parenting skills, 
children and pupils are provided with education as well as information, psychological and special pedagogical help, moreover, various out-of-school activities are organized: clubs, events etc. For adults various courses, distance learning and entertainment are provided. Other activities in this area could be cultural or social: the center could be a library, a reading room, a charity, the hairdresser's, etc. The multifunctional centers will help to create and develop a modern, complex system of educational, cultural and social services in rural areas. It is planned to finance the establishment and development of centers by modernizing and adapting the premises of former small schools, cultural houses, libraries for community use. Premises repairs, equipment and furniture will be financed to accommodate the building to different age groups and their needs. Centers are expected to solve the problem of insufficient quality, supply and accessibility of education and social services in rural areas. According to Aleksandravičius and Žukovskis (2011), principles of successful rural community activities are that communities must be open, learn from their own and other activities, be able to adapt to constantly changing living conditions, should be flexible and receptive to innovations. And this is achieved if community members share the same values; their members trust each other and clearly understand the goals of the local community. Through targeted community activities and in order to integrate the rural population into active social life, creative activities of cultural and sport managers can become one of the important factors in creating sustainable rural development.

\section{Conclusions}

The community is defined as a group of people sharing the same space, similar experiences and / or similar interests, pursuing commonly formulated goals, and the main goal of rural communities is to motivate the population to focus their efforts on improving their living conditions, motivating them for self-development and cultural self-expression, strengthening solidarity, trying to prevent the spread of social exclusion trends.

Activities carried out by rural community organizations cover a wide range of community needs. This includes organizing cultural and sporting events, arranging environmental management tasks, taking care of leisure activities for children and young people, improving rural infrastructure, educating the population, solving rural social problems, representing residents in government institutions and others.

The poor condition of rural social infrastructure objects was mentioned as the main problem of rural community activity, therefore, the process of establishment of community centers in the establishment of Universal Multifunctional Centers is one of the significant tools for the development of rural communities and thus the development of cultural and sports activities. 


\section{REFERENCES}

1. Aleksandravičius, A., Žukovskis, J. (2011). Kaimo bendruomenių raida ir jų veiklos tikslai: siekiant darnumo visuomeneje. Management theory and studies for rural business and infrastructure development, 1 (25).

2. Baršauskienè V., Leliūgienè, I. (2001). Sociokultūrinis darbas bendruomenèje. Kaunas: Technologija.

3. Bilohur, V. (2013). The Philosophy of Sport as a New Science Area and New Educational Discipline. Humanitarian Bulletin of the Zaporizhzhia State Engineering Academy, 54, 138 - 154.

4. Bilohur, V. (2018). Conceptial sport formation as a socia; system, social institute and social movement in conditions of globalization. Humanitarian Bulletin of the Zaporizhzhia State Engineering Academy, 73, 13 - 24.

5. Jasaitis, J. (2014). Kaimiškuju vietoviu strateginis valdymas. Metodinis leidinys savivaldybių darbuotojams. BMK leidykla, Vilnius.

6. Kroeber A., Kluckhohn C. (1952). Culture: A Critical Review of Concepts and Definitions . New York, NY: Vintage.

7. Lietuvos Respublikos vietos bendruomenių savivaldos politikos pagrindų įstatymas, 2016 m. birželio 9 d. Nr., Vilnius.

8. Nefas, S. (2007) Funkcionali vietos bendruomene Lietuvos kaimuose ir miesteliuose. Daktaro disertacija. Vilnius: $M R U$.

9. Nefas, S. (2008). Lietuvos kaimų ir miestelių vietos bendruomenių funkcionalumą lemiantys veiksmai. Viešoji politika ir administravimas, 23.

10.Paulikas, V., Adomonis, V. (2003).) Vietos savivalda ir sprendimų prièmimas. Viešoji politika ir administravimas, 4, 66-73. .

11.Putnam, R. D. (2001). Kad demokratija veiktų. Vilnius: Margi raštai.

ЯРУШЯВІЧЕНЕ, ЛІНА - завідуюча кафедрою права, менеджменту і комунікації, лектор Маріямпольської колегії (Маріямполе, Литва)

E-mail: lin.jaru@mkolegija.lt, ORCID iD: 0000-0002-1058-4877

\section{РОЗВИТОК КУЛЬТУРНОЇ І СПОРТИВНОЇ ДІЯЛЬНОСТІ У СІЛЬСЬКІЙ МІСЦЕВОСТІ}

Анотація. У великих і невеликих сільських поселеннях, незалежно від привернення уваги до туристичної діяльності, культурне життя вимирає, ініціатива людей є низькою, тому що приваблива сила міста $є$ назвичайно великою. Багато жителів етнографічних сіл не розуміють, що вони живуть у важливій для держави міцевості. Проте місцева генерація людей соромиться місцевих традицій, фольклору. Низький рівень естетичного виховання (як музики, так i мистецтва, дизайну, архітектури) та можливостей організації художніх свят для молодого покоління, що перетворює їх на споживачів культури самого низького рівня

Актуальність дослідження. Персонал литовських культурних центрів - група, що об'єднує майже три тисячі людей, запрошених осмислити дозвілля сільських жителів, щоб створити умови для розвитку самодіяльності. 882 заміських культурних центрів у селах, поселеннях i маленьких сільських центрах $є$ установами універсального використання чи установами специфічної діяльності. Їх діяльність вибудовується у залежності від того, які тардиції склалися та які амбіції тих, до яких відносяться місцеві культурні і спортивні відідли району чи общини. Проте не знайдемо центру, у якому б не співали, не танцювали, не святкували ті чи інші події, не відкривалися б виставки. Більш інтенсивна діяльність відкривається у районних центрах, а влітку - на курортах. Тут більше місця, більше спеціалістів культури, більше товариств. Сільські і місцеві установи культури, які постійно спілкуються зі школами, бібліотеками, релігійними 
общинами і спортивними клубами, також отримують більше результатів. Проте 3 теоретичної точки зору доцільно перейти до конкретних даних. Самозайняті члени сільських общин зіткнулися 3 проблемою охорони здоров'я. Недостатня увага приділяється розвитку особистої відповідальності за своє здоров'я і пропаганду здорового образу життя: правильного харчування, активного відпочинку, менш загрозливого для здоров'я оточуючого середовища, відмови від шкідливих звичок і т.п. Важливо розвивати фізично активне і здорове суспільство, усвідомлювати важливість здорового образу життя, створювати достойні умови для дозвілля, зайняття спортом і покращення здоров'я сільського населення, прискоряти розвиток служб фізичного виховання і спорту у сільських місцевостях Литви, підвищувати якість спортивних послуг, надаючи сільським жителям широкі можливості задовольняти свої потреби. У статті розглядається проблема недостачі культурних і спортивних послуг у сільських общинах. Аналіз проблеми базується на статистичних даних робіт Александравічюса і Жуковського (2011), Баршаускене, Лелюгене (2014), Кроебера А., Клуххон (1952), Нефа (2007, 2008), Паулікас, Адомоніс (2003), Путнм (2001) та на документах, що регламентують діяльність сільських общин.

Методологія дослідженя. Мета дослідження - виявити чинники розвитку культури і спорту у сільській місцевості. Задачі дослідження: описати розвиток культурно-спортивних послуг у контексті діяльності сільських товариств; виявити найбільш значущі чинники розвитку культурних і спортивних послуг у сільській місцевості. Для досягнення цілі викорстовується аналіз і узагальнення наукової літератури, правових документів, інших джерел інформації та статистичних даних.

Виновки. Заходи, що проводяться організаціями сільських товариств, включають ширкий спектр суспільних потреб, включаючи організацію культурних і спортивних заходів, покращення допомоги у сфері управління оточуючим середовищем та інше. Основною проблемою діяльності сільських товариств є стан об'єктів соціальної інфраструктури, тому процес створення універсальних багатофункціональних центрів $\epsilon$ одним 3 важливих інструментів розвитку сільських общин, а, отже, розвитку культурної і спортивної діяльності.

Ключові слова: товариства, сільські товариства, розвиток, культурні послуги, спортивні послуги.

ЯРУШЯВИЧЕНЕ, ЛИНА - заведующая кафедрой права, менеджмента и коммуникации, лектор Мариямпольской коллегии (Мариямполе, Литва)

E-mail: lin.jaru@mkolegija.lt, ORCID iD: 0000-0002-1058-4877

\section{РАЗВИТИЕ КУЛЬТУРНОЙ И СПОРТИВНОЙ ДЕЯТЕЛЬНОСТИ В СЕЛЬСКОЙ МЕСТНОСТИ}

Аннотация. В больших и в небольших деревнях, независимо от туристической привлекательности, культурная жизнь угасает, инициатива людей низка потому, что притяженние города чрезвычайно высока. Многие жители этнографических сел не понимают, что они живут в значительной для государства местности. Молодое поколение смущается местных традиций, фольклора. Низкий уровень эстетического воспитания (как музыки, так и искусства, дизайна, архитектуры) и возможности организации художественных праздников для молодого поколения превращают в потребителей культуры самого низкого уровня.

Актуальность исследования. Персонал литовских сельских культурных центров группа, объединяющая почти три тысячи человек, приглашенных осмыслить досуг сельских жителей, создать условия для развития самодеятельности. 882 загородных культурных центров в деревнях, поселках и городках являются учреждениями универсального использования или учереждениями специфической деятельности. Их деятельность, в зависимости от того, какие традиции сложились и какие амбиции, к 
которым стремятся местные культурные и спортивные отделы района или общины. Не найдем культурного центра, в котором бы не пели, не танцевали, и не праздновали, не открылась бы выставка. Более интенсивная деятельность происходит в районных центрах, а летом - на курортах. Здесь больше места, больше специалистов культуры, больше сообществ. Сельские и городские учреждения культуры, которые постоянно общаются со школами, библиотеками, религиозными общинами, районными и спортивными клубами, также получают больше результатов. Однако с теоретической точки зрения целесообразно перейти к конкретным данным. Самозанятые члены сельских общин сталкиваются с проблемой здравоохранения. Недостаточное внимание уделяется развитию личной ответственности за свое здоровье и пропаганде здоровой жизни: правильному питанию, активному отдыху, менее опасной для здоровья окружающей среде, отказу от вредных привычек и тому подобное.. Важно развивать физически активное и здоровое общество, осознавающае важность здорового образа жизни, создавать благоприятные условия для досуга, занятий спортом и улучшения здоровья сельского населения, ускорять развитие служб физического воспитания и спорта в сельских районах Литвы, повышать качество спортивных услуг, предоставляя сельским жителям более широкие возможности удовлетворить свои потребности. В статье рассматривается проблема нехватки культурных и спортивных услуг в сельских общинах. Анализ проблемы основан на статистических данных работ Александравичюса и Жуковского (2011), Баршаускене, Лелюгене (2014), Кроебера А., Клуххон (1952), Нефа (2007, 2008), Пауликас, Адомонис (2003), Путнм (2001) и на документах, регламентирующих деятельность сельских общин.

Методология исследования. Цель исследования - выявить факторы развития культуры и спорта в сельской местности. Задачи исследования: описать развитие культурно-спортивных услуг в контексте деятельности сельских сообществ; выявить наиболее значимые факторы развития культурных и спортивных услуг в сельской местности. Для достижения цели используются анализ и обобщение научной литературы, правовых документов, других источников информации и статистических данных.

Выводы. Мероприятия, проводимые организациями сельских сообществ, включают широкий спектр общественных потребностей, включая организацию культурных и спортивных мероприятий, улучшение помощи в области управления окружающей средой и другие. Основной проблемой деятельности сельских сообществ является состояние объектов социальной инфраструктуры, поэтому процесс создания универсальных многофункциональных центров является одним из важных инструментов развития сельских общин и, следовательно, развития культурной и спортивной деятельности.

Ключевые слова: сообщества, сельские сообщества, развитие, культурные услуги, спортивные услуги.

Стаття рекомендована до публікачії д.філос.н., проф.М.А.Лепським (Запоріжжя, Украӥна) Надійшла до редколегіï: 07.06.2019 p. Прийнята до друку: 17.06.2019 р. 